Portland State University

PDXScholar

Political Science Faculty Publications and

Presentations

Winter 2017

\title{
In the Shadow of the 2016 Election: Immigration Debates in Oregon and Beyond
}

Kim Williams

Portland State University

Andrea Williams

Causa

Phil Carrasco

Grupo Latino de Acción Directa (GLAD)

Follow this and additional works at: https://pdxscholar.library.pdx.edu/polisci_fac

Part of the American Politics Commons

Let us know how access to this document benefits you.

Citation Details

Williams, K., Williams, A., \& Carrasco, P. 2017. In the Shadow of the 2016 Election: Immigration Debates in Oregon and Beyond. Oregon Historical Quarterly, 118(4):612-629.

This Article is brought to you for free and open access. It has been accepted for inclusion in Political Science Faculty Publications and Presentations by an authorized administrator of PDXScholar. Please contact us if we can make this document more accessible: pdxscholar@pdx.edu. 


\title{
In the Shadow of the 2016 Election
}

\author{
Immigration Debates in Oregon and Beyond
}

\section{PANEL DISCUSSION}

by Kim Williams, Andrea Williams, and Phil Carrasco

DURING A LUNCHTIME SESSION, on Tuesday, November 17, 2016, Daniel J. Tichenor of the University of Oregon Wayne Morse Center for Law and Politics moderated a panel discussion about immigration in the United States and in Oregon following the 2016 presidential election. The panel included Kim Williams, associate professor of Political Science at Portland State University; Andrea Williams, executive director of Causa; and Phil Carrasco, president of Grupo Latino de Acción Directa (GLAD). A transcript of the discussion, edited for publication, appears here.

KIM WILLIAMS (KW): First, I want to talk about how important immigration became in this election. Then l'll talk about how [Donald] Trump actually won. Finally, I'll discuss the implications of his victory. I really expected a different election outcome, and so, I'm still wrapping my mind around what actually happened. In the end, immigration emerged as a central issue in this election. This is in part due to the fact that president elect Trump kicked off his campaign with the insinuation that Mexican immigrants are rapists. That's how he started the whole thing: "When Mexico sends its people, they're not sending their best. . . . They're sending people that have lots of problems, they're bringing these problems with [them]. They're bringing drugs. They're bringing crime. They're rapists. And some, I assume, are good people." So, needless to say, the candidates held starkly different views on immigration policy. Hillary Clinton wanted a path to citizenship. She wasn't interested in a Muslim ban. She wanted to welcome refugees. She opposed a border wall. She would have kept DACA (Deferred 


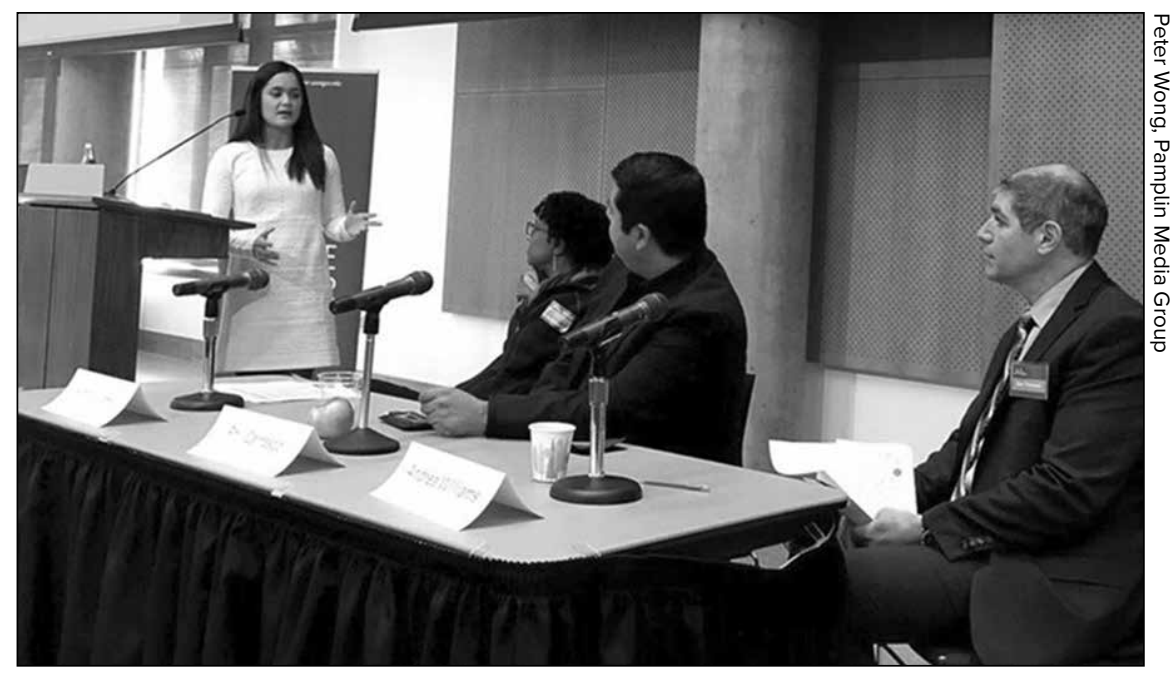

ANDREA WILLIAMS (LEFT), Executive Director of Causa, presents alongside two other panel members. From left to right are Kim Williams, associate professor at Portland State University; Phil Carrasco, President of Grupo Latino de Acción Directa (GLAD); and moderator Dan Tichenor, University of Oregon Wayne Morse Center.

Action for Childhood Arrivals) intact, which I'm sure my colleagues will speak more about. She wanted to keep the Fourteenth Amendment as-is. Donald Trump, on the other hand, [is] pro-deportation. He's for a Muslim ban, and he supports keeping refugees from Syria and other countries out. He says he's building the border wall, and Mexico's going to pay for it. He wants to revoke DACA, and he's interested in ending birthright citizenship, which, again, is protected under the Fourteenth Amendment. How did he win? You look at the electoral map, and some of these states [that he won] - I was shocked: Pennsylvania, Ohio, Wisconsin, Michigan. Those rust belt states, really, is how he won. Florida, of course, as well, which I thought was going to go the other way, and it didn't.

How did we get to where we can elect someone who has no experience in government, and actually denigrates government, and, as Hillary Clinton said, "trashes our democracy," in the sense that it wasn't clear if he was going to accept the election results had he lost? Public trust in government is down to abysmal levels in our country, and arguably, that's part of the reason why he won, because really, he ran on a campaign of "You can't trust the government, this system is rigged, et cetera, et cetera." Part of it, too, is that we have dismally low turnout in primary elections and mid-term elections. We're looking at a [small] percent of the voting age population that's 
even showing up to vote in primary elections to decide who's going to end up in the general election. ${ }^{2}$ When you've got these kind of numbers, you know that's part of the problem. A lot of people have a lot of complaints about Congress. But, again, when you look at the percentage of Americans who are actually voting in mid-term elections, it's even worse than presidential elections. And so, we certainly have a serious problem with voter turnout.

Here [on this slide], you're looking at turnout in 2016. This is still a workin-progress; some of the votes are still being counted, and analysts are still figuring this out. Right now, it looks like we're at about 58 percent of all eligible voters who cast ballots. I like cartoons. [refers to slide] “We didn't vote 'cause it won't make a difference." I'll just say that I personally have just had it with the people who want to complain now about what happened: "What could we have possibly done?" Well, you know what? You could have voted.

This slide shows that the Republican Party is increasingly dependent on White voters. So, you look at Mitt Romney, 92 [to] 93 percent of all the votes that he got came from White people. Donald Trump is in the nineties as well. So, the G.O.P. is increasingly dependent on White voters, but the G.O.P. share of the Latino vote has been going down. I was under the impression that, mathematically, it was absolutely impossible for anybody to win a presidential election unless they won at least 40 percent of the Latino vote. That's what l've been taught. That's what I believed. That's what I thought was true. Turns out, that's not the case. Why? Arguably, this election is an anomaly, because this trend is still a problem for the Republican Party. We really only have two political parties, and if [for] one political party, almost all of the votes are coming from White people, it's not sustainable! So, I do believe that this election is unique. Why would that be the case? Well, when we look at how Donald Trump actually won this election, we've got 58 percent of Whites who were voting for Donald Trump and only 37 percent of Whites who voted for Hillary Clinton. She's got a much more diverse coalition that's behind her. But look [at this slide reporting] education by race. We're looking at 67 percent of White people without a college degree, who are voting for Donald Trump. He won this election on the backs of White people without college degrees, largely males. Those people came out in droves, and that's why this model did not apply in this particular election. These models are not actually taking into account the idea of such overwhelming White male turnout among lower-educated voters. This [slide] breaks it down in terms of the race and gender of the electorate. You're looking, for example, at White men, who were 34 percent of the total electorate in this election; 63 percent of those people voted for Donald Trump.

There's not much here to be really all that pleased about, in my opinion. For me, personally, it's been hard; I'm sure it's been hard for a lot of people. But, one little bit of solace that I have 


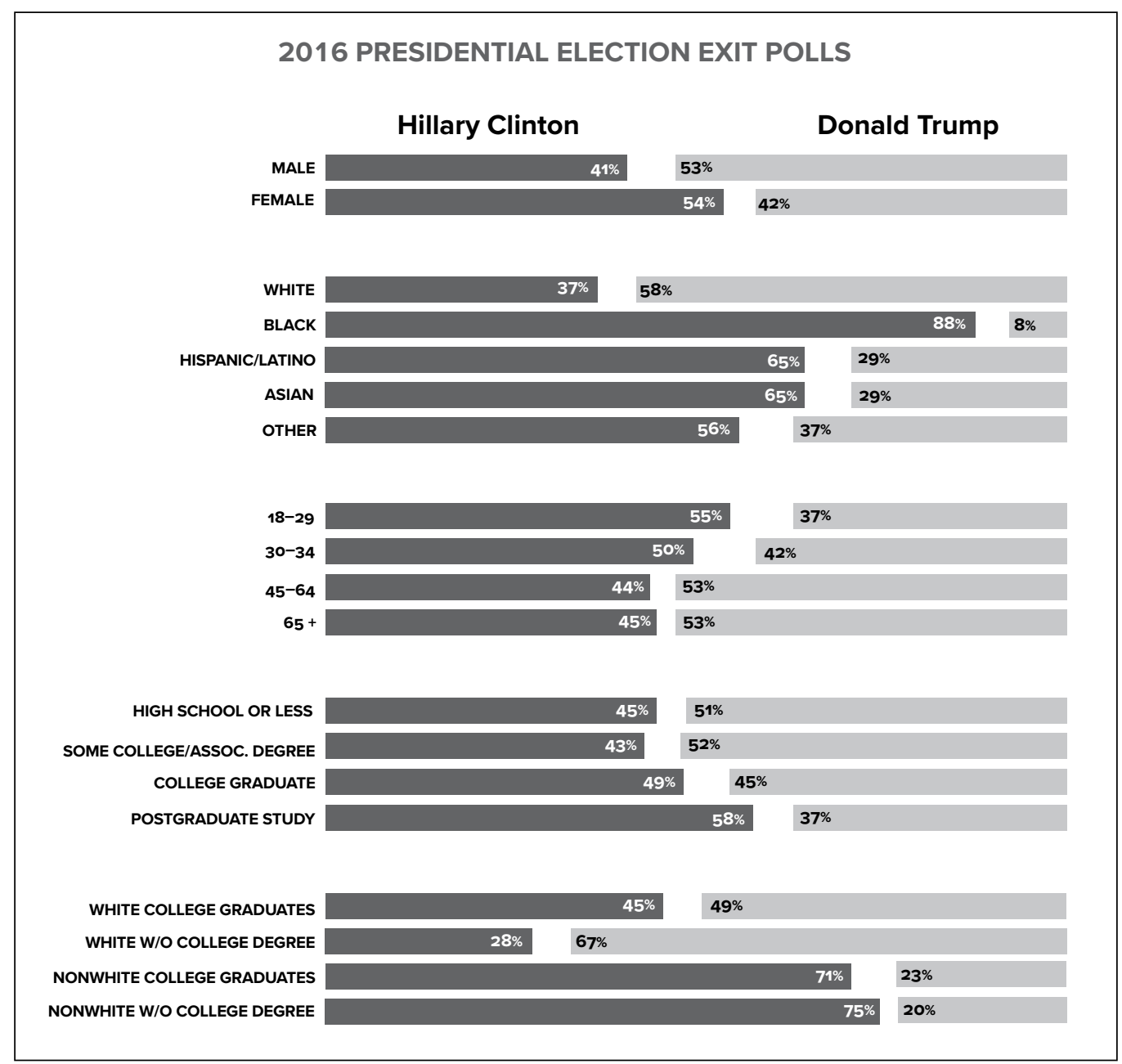

THIS TABLE shows the 2016 presidential election exit polls as reported by the New York Times on November 8, 2016. Kim Williams referenced statistics taken from these exit poll figures in her lunchtime presentation on November 17, 2017. The full results can be found at https://www.nytimes.com/interactive/2016/11/o8/us/ politics/election-exit-polls.html.

is when you look at the Black women, 93 percent of Black women are voting for Hillary Clinton. So, you know, it's not my people! I think this election, in many ways, is about White people talking amongst themselves to try to figure something out. What kind of direction is the country going to go in? Because if it had been up to Black people, Hillary Clinton would be the president of the United States (president elect).

I'm still trying to figure out how to even understand what happened here. In my "Women in Politics" class, 
the last day, right before the election, we were talking about Arizona going blue; that was just a fantasy, apparently. But I still don't understand. Here [slide] we're looking at Obama in 2012 compared to Clinton in 2016. Looking at women who are voting -55 percent of women voted for Obama in 2012, 54 percent of women voted for Clinton in 2016. But look at Trump. I thought it was offensive when Mitt Romney said "binders full of women." Do you remember that? What has happened since then, in these four years? We can go through the myriad derogatory and insulting statements that Donald Trump made about women, but it seems not to have mattered! Mitt Romney won 44 percent of the women's vote in 2012, and Donald Trump wins 42 percent! I don't have an answer. I'm struggling to try to figure that out.

Look at the Latino vote as well. President Obama won 71 percent of the Latino vote in 2012; Hillary Clinton won 65 percent. We started off talking about Mexicans as rapists, that's where we started this talk. I do not understand how it is that the Latino support for Hillary Clinton was less than what it was for Barack Obama a couple years earlier. By these exit polls that we have now, 29 percent of all Latinos - almost one out of three - voted for Donald Trump, given all of what he said. The implication of Trump's victory is that life is just going to get harder for immigrants. I think that's really the bottom line. Hopefully, my colleagues will have something positive to say.

Last few things: Kris Kobach - just as one example - is the Kansas Secre- tary of State, and he was the architect of the Arizona law, and he's going to have a prominent role, apparently, in the Trump administration. He's the guy who came up with the bright idea of how to pay for the wall [on the Mexico-United States border] by holding remittances from Mexican Americans. ${ }^{3}$

I'm going to close out on a couple of questions that I'm thinking about, and I don't know how to answer them. Can the G.O.P. follow through with any of Trump's promises? Before this election, we were talking about the Republican Party splintering, just falling apart. And now that they've won everything, it still is unclear. They still have a lot of internal differences amongst themselves. It'll be interesting to see how they negotiate all of that, because to many people - the kind of mainline Republicans, the Paul Ryans of the world, the ones who said that Donald Trump is a textbook racist case - I don't know how those people coordinate with each other. And we'll be watching. I'm interested in the political coalitions that can fight back, and I'm interested in hearing more from my colleagues about how they see all that playing out. So, thank you.

ANDREA WILLIAMS (AW): Hi everyone! I'm Andrea Williams, no relation to Kim Williams (it's a nice coincidence). I'm the executive director of Causa, a Latino immigrant rights organization based out of Salem. We've been around since 1995, when we saw a series of anti-immigrant initiatives on Oregon's ballot. We came together as a coalition and started fighting back. 
Kim gave us a nice overview of what this means nationally, and I would like to focus on what this means for the state of Oregon, and what it means for advocates here.

But before I do that, I did want to politely challenge one of the points made on these exit polls. Kim had said "Why would the exit poll show us that the Hispanic vote went down for the Democrats?" I've read multiple other exit polls conducted by Latino researchers that have the capacity to do more in-depth polling among Latino voters, and they actually found a different conclusion. They found that Latino voters turned out in droves for the Democratic Party; they turned out like never before. Again, going with Kim's line - "Our community did our work" - I would say the Latino community did their work as well. In fact, the exit poll [Kim Williams cited] said that Clinton's margin was 65 to 29. But the exit poll done by Latino Decisions was actually 78 percent for Clinton, and 19 percent for Trump. ${ }^{4}$ So there's a tenpoint difference between the general exit polls and what Latino Decisions conducted. Why is that, you ask? Look at our polling instruments that we use now, and how much they've failed us, how much they said Clinton was going to win. We are now learning the lack of reach that some of these polls have. The polls indicate who they were able to actually talk to. They missed entire swaths of White working-class folks, which resulted in polling that indicated Hillary was going to win. And clearly that wasn't the case. The same goes with a lot of other communities, like
Latino communities. Some theorize that the general exit polls were only reaching Hispanic voters that spoke English. That's a particular type of Latino voter. There are a lot of Spanishspeaking voters that were not reached through these polls. And that's exactly what research agencies that specialize in reaching particular communities are good at. Alright, so, l'm done lecturing on that point.

Let's take a look at some of the state election results. I want to start with a good piece of news. Oregon elected its first Latina immigrant to the state legislature ever, representing House District 22, and House District 22 is Woodburn and northeast Salem. And if you're familiar with that community, 80 percent of their high schoolers are Latino. This is the first time having a Latino representative represent a majority Latino community, which is extremely exciting. I would love to see Oregon become more reflective of the communities that actually exist here. We're 20 percent people of color, and when you go to the state legislature, it's mostly old White men! And a lot of them are allies and support our work. But, in my opinion, if we want an actual democracy, it's going to reflect the diverse opinions and communities that exist here. Others were elected to city council and school board positions; you should take a look at what your local election results were.

I guess the only second good news is that Oregon pretty much maintained its progressive majority in the state legislature. We elected Governor Kate Brown again, we elected a similar 
makeup in the house. The senate lost its super majority, but it's still majority Democratic. So, more or less, things haven't changed dramatically at the state legislative level.

Two big things really did impact our future here as the state of Oregon. First is the election of Dennis Richardson as Secretary of State. Dennis Richardson is on record for being anti-immigrant and anti-gay, and the Secretary of State administers our elections. They make it more or less accessible for people to register to vote. They make it more or less easy for people to vote by mail, or to have any language information. And I don't think any of that is on Dennis Richardson's agenda. In addition, the Secretary of State is in charge of qualifying ballot measures. They count all the signatures that are turned in by citizens to say "I want this law on the ballot," or not. And l'll talk more about why that's important a little bit later. In addition, he's in charge of auditing non-profits, businesses, you name it. So, that is something to look out for in terms of our future as a state. And then, we lost Measure 97, which would have provided much-needed revenue for the state of Oregon. We are now projecting a $\$ 1.7$ billion deficit, or gap, which puts into question a lot of issues that Causa was hoping to advance in the next legislative session. We're not going to stop, but it certainly makes our job a whole lot harder. So, that's some general things to think about in all of the issues that we care about moving forward. And my basic message to you all is, although the national scene looks really scary, and it will be, we need to believe every word that president elect Donald Trump says. We have no other reason to believe he's going to do something different until we see otherwise. Oregon has an opportunity, though, to go a different direction. We're not a perfect state, but we have a chance. We have a chance to go a different direction through our local governments.

So, I want to talk about, first, the challenges, and then some of the opportunities, and then l'll hand it off to Phil, to talk about the opportunities here in the local area. In terms of Oregon being a better state, the "welcoming" state, the "inclusive" state for every community, countering Trump's rhetoric of hate and exclusion, we have our own problems here in Oregon. You know, a lot of us think Oregon is pretty good, we're pretty progressive, we're pretty supportive of most communities, but we have some hateful organizations that do exist here in the state. There's an organization called Oregonians for Immigration Reform, or as we call it, OFIR, by their acronym. They're an anti-immigrant organization that believes in passing policies that make life so hard for immigrants in the state that immigrants just self-deport. We all know that that's not how it works. People don't just self-deport. They were behind, for example, referring the Safe Roads Act, which would have provided immigrants a legal way to drive in our state, to Oregon voters, in 2014. It was Measure 88, 
which then lost, so undocumented immigrants no longer have a way to legally drive. That's one example of ways that they've tried to dismantle some of the progress we've made. And they're emboldened now. They were emboldened in 2014 when they were successful in taking away driving privileges, and they've been emboldened now that Donald Trump, someone who has taken on their agenda, in a very clear and public way, [has won election]. They already have tried to qualify several initiative petitions.

Initiative petitions are the process before something becomes a ballot measure. You have to get a ballot title, you have to collect 1,000 [sponsorship] signatures. Once you get that done, you have to collect another 100,000 signatures from Oregon voters in order for a ballot measure to be on the ballot. And then, Oregon voters get to say "Yes" or they get to say "No." It's a very simple process.

OFIR is looking at trying to take away a very important Oregon state statute that protects immigrant families, and reduces ICE [Immigration and Customs Enforcement]-police collaboration, which is a really key way that people get deported very quickly. They want to take that away. They want to make it harder to register to vote in the state, which actually impacts all of us here, not just immigrants. They want to implement things like English-only [policies]. I thought we were over this thinking, in the Nineties. But they're bringing it back. They're bringing back [proposals] like: government agencies cannot provide services or information in languages other than English. When you think about it, isn't being multilingual an asset? Since when was it like a bad thing to provide information in multiple languages? So they're trying to qualify those types of things for 2018 , a mid-term election. If you're familiar with turnout, mid-term elections don't do really great for progressive issues or for Democrats, or for anything having to do with immigrants. Generally, our popular vote process is not favorable towards immigrants, I would just say, regardless of presidential or mid-term election, but mid-term elections tend to be pretty bad. So, they're trying to qualify these ideas, and to me, it's a way for them to implement Trump's agenda on the ground. So, that's a challenge that we're actively looking to stop.

We've developed a coalition called One Oregon. One Oregon is actually a coalition of organizations like Causa, but across the board: environmental, pro-choice, other communities of color coming together and saying, "We will not stand for these types of issues." And so, we are actively working to stop those. Now, we turn to opportunities, really quickly.

I said earlier that we had an opportunity to change, right? We can be different than the rest of the nation. I'm not saying that we are now, but we can be if we have an opportunity. What we're doing right now - just like so many of you here - we're all processing this, and we're all trying to figure out what to do. None of us anticipated this result, so therefore, 
we did not have pre-crafted policies that we could then ask the governor to take on. So, we're in that process right now. And our goal is to find ways that we can strengthen current law to protect immigrant families, while also not letting go of our agenda.

We want healthcare for all kids! There are 17,000 immigrant children in Oregon that go to our schools. They don't have any healthcare. ${ }^{5}$ That's not good for the rest of the student body! It's just not. That's how communicable disease gets spread, that's how colds spread, and if one kid gets sick, they go into the classroom, all of the kids get sick. So, we want healthcare for all the children. That's been on our plate for the past five years, and we're not going to stop. We need to say "We don't want these things, but here's what we do want. Here's what we envision for our state."

There's going to be a bill to reduce and actually hold accountable law enforcement technique, types of racial profiling, and other types of profiling that happen. So, there's actually a really exciting agenda under what we call the Fair Shot Coalition that we will see in the next legislative session. We're not giving that up. But in the meantime, we also need to look at: "How can we strengthen Oregon policy when it comes to Immigrants?" As you probably have seen in the news, Portland State [University], $U$ of O [University of Oregon], OSU [Oregon State University] are all passing what they call sanctuary policies, which is a way to say "we're not going to provide any information or collaborate, or put any resources towards helping implement federal immigration deportation processes." We're building our own wall here in our community, to say, "ICE is not allowed here, and they will not touch our students, they it will not touch our families." And that's exactly what we need to be doing right now at the local level. So with that, I'm going to hand it to Phil, and he can tell you more about that.

PHIL CARRASCO (PC): Mucho gracias Kim and Andrea. My name is Phil Carrasco, and I'm the president of Grupo Latino de Acción Directa [GLAD]. Our focus has been here in Lane County, to be able to identify the issues that our Latino population cares about most. There's been many tries at this, and we found that during this time, it's important that we make sure we create the spaces necessary for the Latino community to actually sit down and learn how to have a conversation amongst themselves. Maybe not so much learn, but really just to have that space available to them. Grupo Latino de Acción Directa prides itself in creating a space, bringing [together] the key players that can make decisions on these issues, have the Latino population have the conversation, and immediately kind of extract themselves from the process. Why? Because there's nothing more beautiful than seeing a lot of folks that have been beaten down by the system that we're facing, thinking that there is no voice, that there is no real power, and being able to see that light, that fire, just really ignite, is 


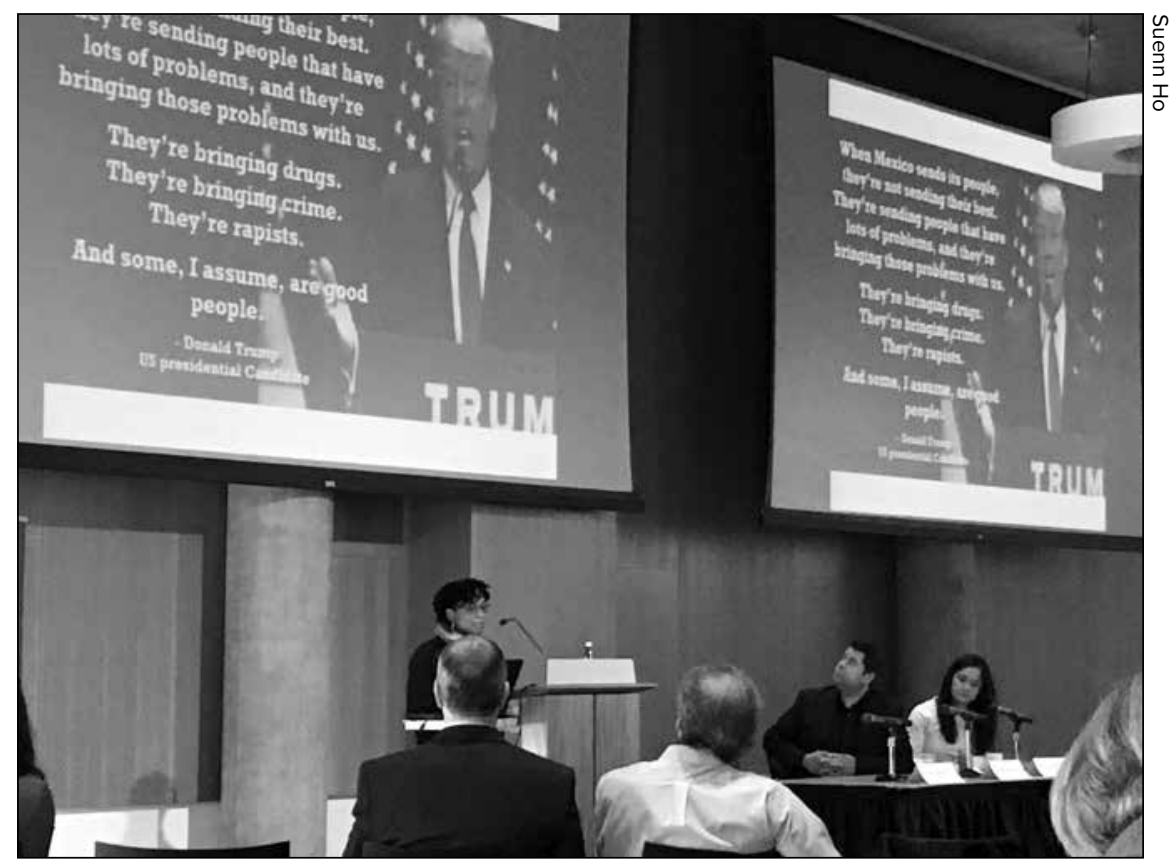

KIM WILLIAMS, Associate Professor of Political Science at Portland State University, speaks about how immigration played a large role in the 2016 presidential election during a lunchtime panel at the Oregon Migrations symposium on November 17, 2017.

a very powerful thing. Our topics are around education, health, economy, but we do not at all ever shy away from the politics. That's something that I think non-profits have done for so long, and even 501(c)3s have the luxury or the privilege to be able to stand by certain ballot measures, to support them or not.

GLAD's work is, I think, superimportant in creating the type of movement that we need, and obviously always being very genuine with our intention. We were proud to partner with Causa, our state's leading immigration advocacy group, with Measure
88. We organize beautifully against these initiatives, [such as] English only, and we were able to just build on what we had started with Measure 88.

We're in Eugene and Springfield, and l'd like to kind of just put a little focus on Lane County as a whole. We do have rural areas, but at the state level, we have become a very key player in making sure that not only the Portland metro area, but the Eugene and Springfield metro areas, are key players in establishing statewide policies.

Measure 97, for example, we lost at the Lane County level by 5 percent. 
So, let's go back to the Latino population. Lane County was 8 percent Latino population, and 22 percent of that population is under the age of ten. This is data that came up through $2010 .{ }^{6}$ This is six years later, so they are ready to vote two years from now. They're ready to participate.

Andrea and I were talking about one of these DACA recipients. They're very resilient. They are not their parents, they are not their uncles, they are very resilient, and they keep fighting. And they're very vocal. They're very unapologetic about their existence in this world. And that is a very powerful thing.

We need to start looking at what opportunities we have. Andrea alluded to it a little bit, for example, some of the decisions that have been made at the law enforcement level. There is a movement now afoot to make Eugene and Springfield sanctuary cities; we have the support of the Human Rights Commission for the city of Eugene, and now the Diversity Committee is going to entertain this idea in Springfield.

Before November 8, GLAD had a forum, where we had about eighty people show up here on campus. Seventy-five percent of these attendees were Latino youth. And it told us so much. It spoke volumes as to who was truly invested in the outcome of November 8 . We invited all the local [political] parties. I had no idea who was going to respond, who was going to want to speak to an audience like this. The Lane GOP [Republican Party] showed up. The Green Party showed up. And, the Democratic Party of Lane County showed up. Now, when you get down to the very local level, you don't have the luxury of detaching yourself. These are people you see at any of these stores, at the mall, at the movies, at any restaurant you may go to. The Lane GOP representative was actually full-on Latino, has family that actually lives in Mexico, and is fluent in Spanish. But everything that was coming out of his mouth was saying, "Hey, Trump is really for you guys!" And he had this long chat about how that's who you should vote for. There was an older White gentleman who was representing the Green Party. No surprise there, right? Then there was a young woman of color representing the Democratic Party in the county. However, I will say, regardless of my own affiliation, they all fell short with the questions that were being asked of them by these youth. They used the A-word - amnesty. We used to be talking about comprehensive immigration reform. Why are we talking about amnesty? I'm a product of the 1980 amnesty that was granted to my parents that were undocumented, and I was old enough to see the immediate difference in our quality of life. All of this information just kind of converges into our present reality.

To jump over to Eugene and Springfield, making them a sanctuary city, we do believe that the Eugene Police Department and the Springfield Police Department should provide some real statements, and real teeth 
to local policies, indicating that they will not comply with Immigration Customs Enforcement. They used the words "sanctuary city," because it actually gives much more of a moral high ground. We want to protect our immigrant population, but there's other folks that are being attacked, and potentially going to be attacked. So we've also requested that we ask and direct the Eugene and the Springfield Police Department, and any institution, to not establish a database, a registry, on Muslims. Those are such ridiculous ideas that we just don't want to spend any time thinking about this because it's ridiculous. But this is not going away. So we're asking the police departments to not keep tabs or registry on Muslims.

Going a little step further, thinking about the folks that generally advocate for these type of communities, social justice activists, that, despite being U.S. citizens, are under constant surveillance. When a police officer goes up to an activist, or a protester, and is like "You're under arrest," and another activist grabs at that activist, trying to pull them back, they cause a "reverse lynching." It's just another way of saying "obstructing" law enforcement. So, we also need to instruct our Eugene Police Department, our Springfield Police Department, our sheriff's department, to not keep any tabs, and not cooperate with federal programs that keep tabs on Black Lives Matter, on Chicano movements, on noted Dakota Access Pipeline activists, or any other groups advocating for our underrepresented communities. This is extremely important. These communities are interlocked. You could have a Black Lives Matter activist, a U.S. citizen, out there at the front lines, but is married to somebody that may be undocumented, or has a tia [aunt] that's undocumented. So, there's a bunch of meetings that were scheduled in a flurry, and I want to commend the City of Eugene Human Rights Commission, thank you so much for stepping up to help. We're going to sit down and have something really comprehensive to present to City Council. We do want your support.

DAN TICHENOR (DT): I want to open up to a broader spectrum now, but I want to get the first question out here. Somebody mentioned the sanctuary city movement, sanctuary campuses, which have caught on like wildfire recently. We know that in the Republican house, the Republican senate, and now on the Trump transition team, there are folks who, for several years now, have pushed hard for the notion of basically penalizing sanctuary cities, and now, some folks who are in the Trump transition team are now also punishing sanctuary campuses fiscally. So, I wondered what you all think about this potential challenge to sanctuary cities and sanctuary campuses.

AW: That's a really good question, and I'll be completely transparent with you; we're still researching what 


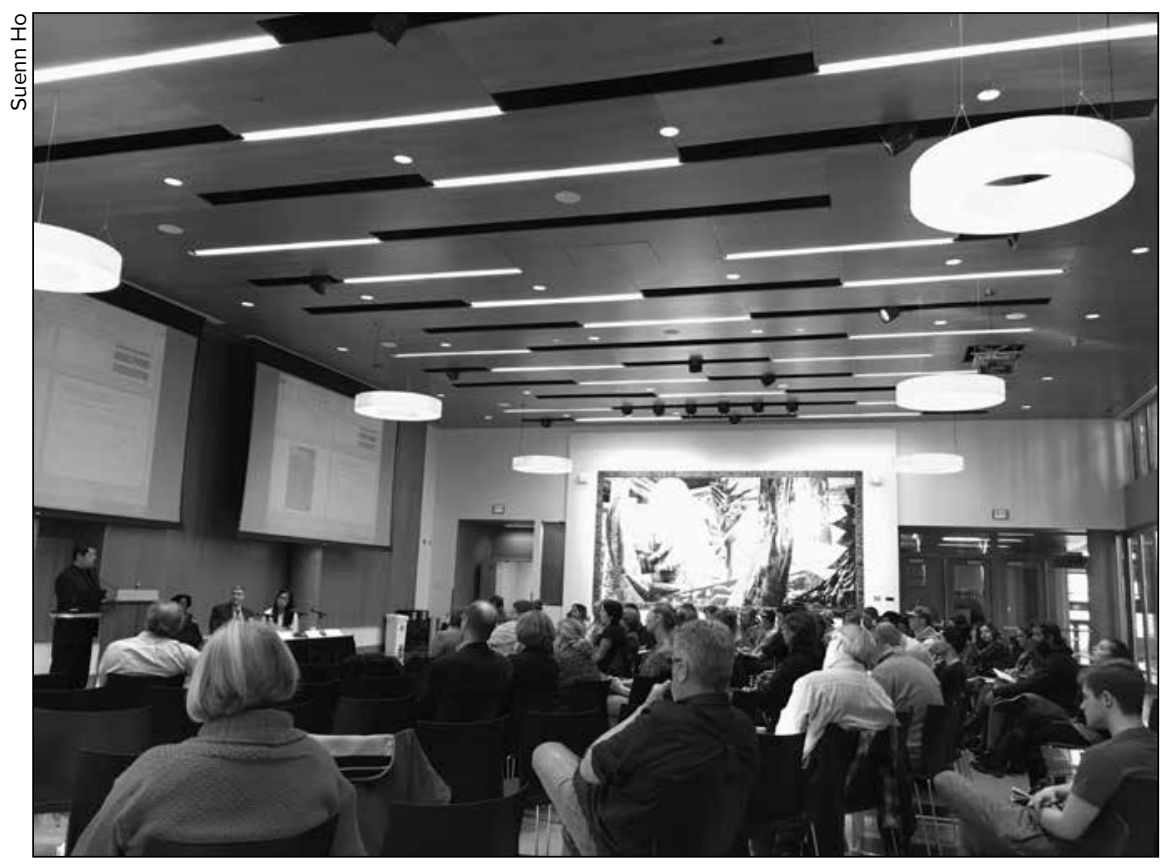

PHIL CARRASCO discusses the work of Grupo Latino de Acción Directa (GLAD) and how it would be impacted by the recent election as a full room listens. The organization focuses on identifying issues in the Latino community in Lane County, Oregon.

that actually means. We are not 100 percent sure what is possible in terms of them revoking federal funds. So we're still looking at that. What I will say, is, just think about this: In a world where we're in a $\$ 1.7$ billion deficit, is the best use of our limited resources helping the federal government do their job? I would much prefer that our local law enforcement is taking care of the people here, instead of being preoccupied with enforcing federal laws. That is the work of ICE. That's not the work of our local sheriff. So, I think there's a really critical argument to be made in terms of resources. It's really an unfunded federal mandate. Where is local law enforcement going to get the money? They're already strapped in rural communities. How would they possibly add this huge job to their plate when they're already struggling with keeping local communities safe and away from crime? That's the question I would rather ask, but I totally understand that the federal piece is 
important and we're still looking at the other paths.

PC: Well, that certainly is a concern, the federal funding. I'm sure that's something that I'm not going to shy away from, but it's a matter of looking at both sides. What if so many cities, and maybe some states, begin to declare themselves sanctuary states or cities? What are people that consider themselves conservatives and against big government going to do? And on our side, when we're grappling with this, and we're talking about potential withdrawal of federal funds, what are we going to say? Will we take that chance based on our values? Are we going to make decisions based on our values and our worldview? Our love, or are we going to make a decision based on fear? I would urge all of us to really look back at our values to make these decisions.

AW: Thank you. So, the question was to talk more about [ORS 181.850], which is a state-level statute that I mentioned that was passed in 1987. It's basically a state law that says local law enforcement cannot spend resources, equipment, or other staff time on enforcing federal immigration law. And when you look at the limitations of it, it's really just looking at law enforcement. It's not looking at schools; it's not looking at other state institutions. To answer your question: how strong is it, and how's it being used? l'll just say that there are some really good articles out there. After 9/11, the Department of Home- land Security had asked the Portland Police to interview 300 Muslim men simply because they're Muslim. No other reason. They needed help in interviewing these 300 men. And the Portland Police said "No. Because it's against Oregon law, we cannot do it." And so, in this case, it really upheld people's civil liberties and rights at a local level. So that's the one example of where that type of state law was critical in ensuring that we're not profiling people based off of religion, based off of their immigration status, or any other reason.

DT: Maybe we could get our panelists to talk about what kind of state is Oregon in terms of immigrant inclusion versus exclusion? I always thought, personally, Oregon's kind of a puzzle.

AW: If you look at it from a numerical perspective, counting the policies that support immigrant communities, Oregon is behind for the West Coast. Compared to Washington and California, we're very behind. Portland is also behind. We think of Portland as a place that is welcoming of immigrants. Certainly, mayor elect Ted Wheeler has said that recently, but from a policy standpoint, we have a long ways to go to catch up with California and Washington State.

MARIO SIFUENTEZ (MS) (Audience member): How many communities in Oregon - police departments and sheriff's departments - have to accept these rules? 
AW: So that's a really good question. I actually don't know the answer to that at the moment. What I do know is that most counties in Oregon, the sheriff's departments have said, at the very least, that they will not honor ICE detainers without a warrant. And the reason for that is because there was a lawsuit where an undocumented woman was held for longer than forty-eight hours without what we call probable cause, simply because ICE suspected she was undocumented, but she had no other reason to be held in the local jail. She worked with the Oregon Law Center to sue that county, and she won, because it was unconstitutional. So as a result, the counties have said "We're no longer participating." The newest iteration is something called PEP, Priority Enforcement Policy, that came out of Obama's administration, and to my knowledge, Multnomah County Sheriff Mike Reese came out with a letter September of this year saying that he will not participate in the PEP program. ${ }^{8}$

MS: The reason I bring it up is that, when you talk about those sheriff's offices and various different law enforcement officials across the country having short budgets, small budgets, one of the ways in which they're enticed to participate, is federal infusion of cash. Also, there was a lawyer in the 1970s who also sued Polk County sheriffs and the city of Independence for the exact same thing. It was also unconstitutional then. So, that'll continue to happen, so we just have to be vigilant.
AW: Absolutely. Yeah. We'll have to continue to engage our sheriffs' departments.

JO OGDEN (Audience member): Thank you for all your thoughts. As somebody who has researched a lot of ethnic violence and riots, I'm not quite as optimistic that all of this is going to stay within the legal context, and, I'm sort of wondering what your sense is about anticipating, basically, violence, and outside of legal avenues, how to handle that - it's an unfair question.

PC: I will say that the city of Eugene has a department exclusively dedicated to taking in the calls when something like this occurs - yelling out, racial slurs, to graffiti, to outright violence. We do have the Eugene Police Department, specifically Chief [Pete] Kerns; I do believe him to be an ally. We've sat, many times, in really in-depth conversations about our communities. I will say, the great deal of youth joining so many other people of color groups, where they go ahead and have these discussions. And, if any of you have been and hung out with youth at their conversations wow. It is amazing, and you come out, like, ready. So, that's as far as l'd like to go, but I know that there are more in-depth conversations about how they're going to protect themselves moving forward.

AW: So, we've been talking about the legal realm, the policy realm, right? 
But when ICE, [which] has a lot of resources, and they can go knocking on doors of DACA recipients, for example, that's where there's very little the state can actually do. And that's where we actually have to go into a different set of tactics, grassroots tactics, where we find homes and churches and other locations for people to take refuge for the time being. And l'll tell you that it has worked in some cases. I was just talking to someone in here about [how] they had this network of churches that took in people during the 1980s, and, we're going to have to return to that era if we see the level of deportations that Trump is promising.

PC: I will add that in Lane County, we are so lucky to have folks that have been here for so long, and seeing these kind of waves of deportations. They have a great deal of context of what happened then, and it kind of helps us redirect our efforts many times.

AUDIENCE MEMBER: So, first of all, l'd like to thank you for your time and knowledge. l've heard of a lot of, you know, events of action have been planned for the future, and l'd like to know: is there a plan to use the power of the media, such as Trump and the anti-measure 97 supporters, have done? Do you see that happening?

AW: Yeah, that's a great question. And I think the media plays an incredibly important role, when and if we see a mass level of deportations, or targeting of any community. That's where it's not legal framework, it's not governmental framework. You're shedding light. That's what the media is supposed to do, shed light on a particular instance to create public outrage, or outcry, or consciousness. At Causa, we have integrated into our strategies a media strategy both for Spanish-language media and also English-language media. So we try to be on as many news stations and publications as possible to share stories of immigrants and others who are directly impacted by injustice. It's a key way that we reach an audience that goes beyond our choir. I think the power of people's stories is one of the most powerful things we have.

DT: Speaking of the importance of the media, the next question is from a reporter.

REPORTER IN AUDIENCE: The university (UO) statement says that we won't participate, or we won't provide information, or we won't enforce. With each of those statements, there's a "but" - "Unless there's a court order." How much comfort should students who are undocumented here on this campus take in those statements? How often is there a court order, and could that be an easy thing? Could one federal judge say "Okay, here's a warrant for the whole country" and it's over in five minutes?

AW: We're advising DACA recipients, or Deferred Action for Childhood 
Arrival students, unauthorized students, to consult an attorney. They need to be talking to attorneys right now. The best defense for them is to have, on speed dial, an immigration attorney. We have very little control over what the federal government will and will not do. And precautions should be made. It's not time to break out in hysteria yet, because we don't know what's going to happen. But what people can do is prepare.

AUDIENCE MEMBER: If the election had been different and Clinton had won, you might talk about some of the limitations of the Obama presidency - all the deportations took place, the ability to really get at structural forms of unemployment. Is it possible to keep those ongoing critiques, while taking seriously all the new forms of violence that could break out?

KW: I think that's legitimate; at the same time, I think that where we are right now is a really, really different place, and a really scarier place as they've just laid out. I mean, Andrea is advising children, young people, to go get lawyers. Had Hillary Clinton won this election we wouldn't be talking about that. So, although it's absolutely true yes, there were deportations, yes there were issues under the Obama administration - where we're heading now is just in a very, very different direction. Kris Kobach, in the administration, that wasn't going to happen under [Clinton]. A Muslim ban? I mean, you can't overturn the Fourteenth Amendment, but just the suggestion! I feel like where we're heading now, it's just such an extreme direction compared to where we were. I haven't seen it in my lifetime.

AW: I just want to remind people, too, a Supreme Court justice needs to be appointed, and it is a critical Supreme Court justice. And it's going to be a conservative one. And, let me just also say that President Obama tried to expand DACA to the undocumented parents of U.S.-born children.

\section{KW: That's not going to happen.}

AW: Right. And it was frozen because of the Supreme Court. So the Supreme Court has a lot of say over executive authority and what's constitutional and what's not. And, we're about to have one appointed under Trump's presidency. So, that's just an additional factor.

PC: And, you did mention this earlier, that despite us having to be, just, obviously, reacting to a lot of things, and defending and protecting, we're not going to lose sight of the other fights, our agenda, at the state level. So, this is a time where we ask our allies to sign up. Pick your organization, but pick one. Get on their mailing list. Do what you can to support those causes. This is where we ask you to find a way to integrate. I work for the Oregon AFL-ClO, and they integrate into their strategic plan, every day, racial justice. Not racial justice like, "Oh, that's number four, down here." It's integrated within every one of our strategic directions, integrated into 
your work. Go to your board and say "We need to integrate it. How do we do this?" If this is absolutely not possible, please, two hours a week, to dedicate to a local organization to help them out. And I would strongly urge that you to go to the ones that are in the front lines. I am usually pretty biased to less- institutional type stuff, ironically, but you want to go with those fighters. You want to be there with them. And I see a lot of folks here that, I know they do that. They're part of like three or four organizations. I already see them. But if you're not, right now's a perfect time. Come and help. Please come and help.
1. "Full Text: Donald Trump announces a presidential bid," Washington Post, June 16, 2015, https://www.washingtonpost.com/ news/post-politics/wp/2015/06/16/full-textdonald-trump-announces-a-presidentialbid/?utm_term=.675766c4c9ea (accessed October 9, 2017).

2. Under 30 percent of voters particiapted in the primary election. See Pew Reserach Center, "Turnout was high in the 2016 primary season, but just short of 2008 record," June 10, 2016, at http://www.pewresearch. org/fact-tank/2016/06/10/turnout-was-highin-the-2016-primary-season-but-just-shortof-2008-record/ (accessed October 9, 2017).

3. Kobach helped write Arizona Senate Bill 1070, which "made it a state crime to be in the country illegally." See "SB 1070 author Kris Kobach joins Donald Trump immigration transition team," azcentral.com, November 11, 2016, http://www.azcentral.com/ story/news/politics/politicalinsider/2016/11/11/ sb1070-author-kris-kobach-joins-donaldtrump-immigration-transition-team/93628108/ (acessed October 9, 2017). On remittances, see Robert A. Cronkleton, "Kris Kobach says he advised Donald Trump on forcing Mexico to pay for border wall," The Kansas City Star,
April 10, 2016, http://www.kansascity.com/ news/politics-government/article71095732. html (accessed October 9, 2017).

4. See Latino Decisions, "Lies, Damn Lies, and Exit Polls," November 10, 2016, http:// www.latinodecisions.com/blog/2016/11/10/ lies-damn-lies-and-exit-polls/ (accessed October 9, 2017).

5. The Oregon Legislature passed this measure in the summer of 2017. Estimates of number of children to benefit vary. See "Oregon Extends Health Care to Children Brought to US Illegally," OPB, July 7, 2017, http://www.opb.org/news/article/oregonhealth-care-children-illegal-immigrant/, (accessedOctober 9, 2017).

6. See "Latino Demographics," Liveability Lane Toolkit, http://www.livabilitylane.org/ toolkit/latino_demographics.htm (accessed October 10, 2017).

7. See "Portland decision highlights differing attitudes," CNN.com, November 22, 2001, http://www.cnn.com/2001/LAW/11/21/ inv.portland.questioning/ (accessed October 11, 2017).

8. Reese letter at https://www.mcso.us/ profiles/pdf/statement_ice_holds_101416.pdf (accessed October 9, 2017). 